\title{
ОРГАНІЗАЦІЙНО-МЕТОДИЧНІ ПІДХОДИ ВИКЛАДАННЯ ІНОЗЕМНИМ АНГЛОМОВНИМ СТУДЕНТАМ НА ФАРМАЦЕВТИЧНОМУ ФАКУЛЬТЕТІ ОДЕСЬКОГО НАЦІОНАЛЬНОГО МЕДИЧНОГО УНІВЕРСИТЕТУ
}

\author{
Н. А. Прилипко, І. В. Вишницька, Л. М. Унгурян, О. І. Бєляєва \\ Одеський національний медичний університет
}

\section{ORGANIZATIONAL AND METHODICAL APPROACHES OF TEACHING ENGLISH-SPEAKING FOREIGN STUDENTS AT THE PHARMACEUTICAL FACULTY OF ODESA NATIONAL MEDICAL UNIVERSITY}

\author{
N. A. Prylypko, I. V. Vyshnytska, L. M. Unhurian, O. I. Bielyaieva \\ Odesa National Medical University
}

\begin{abstract}
У статті розглянуто актуальні питання викладання дисципліни “Етика та деонтологія у фармації” іноземцям, які навчаються на фармацевтичному факультеті Одеського національного медичного університету англійською мовою. Проаналізовано організаційно-методичні особливості викладання англомовним студентам, визначено значення рольових ігор у структурі заняття.
\end{abstract}

The article deals with topical issues of teaching "Ethics and Deontology in Pharmacy", for foreign students who study at the Pharmaceutical Department of Odesa State Medical University in English. The organizational and methodical features of teaching English-speaking students were analyzed, the value of role-playing games in the lesson structure was determined.

Вступ. Сучасний етап розвитку українського суспільства характеризується прагненням до інтеграції з світовим співтовариством, особливо у сфері освіти і науки. Щорічне збільшення кількості іноземних громадян, які здобувають освіту у вищих навчальних закладах (ВН3) України, є яскравим відображенням інтернаціоналізації української освіти [1]. Підготовка іноземних фахівців має суттєве значення в цьому процесі, оскільки характеризує конкурентоспроможність випускників на світовому рівні. Пріоритетом навчання у ВНЗ України є отримання високого рівня якості освіти, iї доступності у порівнянні з іншими європейськими країнами, а також зручне географічне розташування та оптимальні кліматичні умови, що позитивно впливає на швидку адаптацію студента.

Одним із головних напрямків роботи Одеського національного медичного університету (ОНМедУ) $€$ навчання іноземних студентів з викладанням англійською мовою за високими вимогами до якості їх підготовки. 3 метою покращення організації

() Н. А. Прилипко, І. В. Вишницька, Л. М. Унгурян, О. І. Бєляєва навчального процесу було проведено роботу з ретельної підготовки фахівців-викладачів із достатнім володінням англійською мовою, створено та поповнено бібліотечний фонд англомовною літературою. Однак існують певні невирішені питання у підготовці іноземних студентів, одним з яких $є$ різні рівні володіння мовою [1, 2], що є своєрідним бар’єром у відносинах “студент-викладач”, “студент-студент”. Важливою проблемою є створення організаційно-методичних підходів викладання англомовним студентам, забезпечення їх навчальним матеріалом з урахуванням їхнього освітнього рівня та комунікативних потреб. Обговорення саме цих аспектів у методиці навчання $є$ актуальним завданням сьогодення $[3,4]$.

Основна частина. Вперше в ОНМедУ на фармацевтичному факультеті у 2015 - 2016 навчальному році здійснено набір іноземних англомовних студентів з Єгипту, Турції та Тунісу. Для вказаного контингенту англійська мова не $є$ рідною, тому потребує особливого підходу до проведення занять. На кафедрі організації та економіки фармації ви- 
кладається дисципліна “Етика та деонтологія у фармаціі”, яка є важливою для становлення особливості фахівця фармацевтичної галузі. Навчання іноземних студентів проводиться відповідно до робочої навчальної програми для спеціальності 7.12020101 “Фармація” на першому курсі протягом одного семестру в загальному обсязі 90 годин. Засвоєння дисципліни передбачає усвідомлення сутності, ролі і методичної основи етики і деонтології у фармації та медицині; отримання цілісного уявлення про розвиток теорії та практики етики і деонтології у фармації та медицині як системи співпраці і життя в сучасних умовах; навчання дотримуватися алгоритму спілкування з пацієнтами, лікарями та колегами аптечного закладу; засвоєння концептуальних основ успішної роботи фармацевтичних, аптечних організацій; вивчення етичних принципів просування лікарських засобів на ринку та надання фармацевтичної інформації; отримання знань про сутність корпоративної культури та ї̈ взаємозв’язок з іміджем фармацевтичного/ аптечного закладу; отримання уявлення про правила мотивації, збалансовану систему показників - основу для мотивації працівників; ознайомлення 3 демотивуючими факторами, які перешкоджають роботі провізорів; навчання розуміти особливості психологічного “портрета” пацієнтів, впливати на характер комунікацій для належного здійснення медичної та лікарської допомоги; вивчення принципів управлінської етики; одержання знань та вмінь з етики бізнесу.

Проведення заняття здійснюється за традиційною структурою:

- формулювання цілей, які допомагають кращому засвоєнню знань, знайомлять студентів із актуальністю даної теми;

- основна частина, що являє собою обговорення теми, виступи, дискусії та виконання командних завдань у вигляді рольових ігор;

- підведення підсумків заняття.

Ефективність отриманих результатів навчання значною мірою залежить від зацікавленості сту-

\section{Список літератури}

1. Проблемні аспекти англомовного навчання в медичних вузах України / В. К. Ліхачов, Л. М. Добровольська, Т. Ю. Ляховська [та ін.] // Світ медицини та біології. 2013. - № 2. - С. 118-119.

2. Майко О. В. Досвід викладання внутрішньої медицини англомовним студентам / О. В. Майко // Вісник дентів, мотивації, яка стимулює їхню активну діяльність.

Для досягнення цієї мети використовується комунікативний підхід, який передбачає побудову процесу навчання у вигляді рольових ігор як моделі процесу реальної комунікації. Будь-яка гра вимагає дотримання певних правил, винахідливого їх використання та створює оптимальні умови для розвитку творчого мислення. Відповідно до піраміди засвоєння знань, розробленої американськими вченими у 80-х роках XX століття, 75 \% інформації засвоюється через навчання дидактичними іграми [5, 6].

Згідно з комунікативним підходом, комунікативні ситуації, що використовуються у навчанні, моделюють типові ситуації реального життя у фармацевтичній сфері спілкування та максимально зближують процеси навчання і реального спілкування. Це відображає поведінку викладача та студентів, предметність процесу тем, ситуацій, які віддзеркалюють інтереси та потреби студентів.

Оцінювання здійснюється за 4-бальною шкалою, відповідно до якої найвищий бал характеризує активну участь на занятті та правильні відповіді на усі запропоновані запитання. Згідно з навчальною робочою програмою на семінарському занятті повинно бути опитано не менше 30 \% студентів. Зазначена методика викладання сприяє підвищенню інтересу до теми заняття і дозволяє викладачу оцінити більшу частину студентів.

Висновки. Організаційно-методичні підходи викладання дисципліни “Етика та деонтологія у фармації” іноземним англомовним студентам, зокрема використання рольових ігор, дозволяють оптимізувати навчальний процес за такими характеристиками, як активність, зацікавленість, рольова діяльність, колективність тощо.

На основі одержаних знань у студентів виникає можливість формування компетенцій працівників фармації щодо: дотримання етичних принципів просування лікарських засобів, надання фармацевтичної інформації, належного спілкування з колегами, пацієнтами, лікарями та здійснення фармацевтичної опіки хворих.

Вінницького національного медичного університету. 2014. - № 2. - C. 588-589.

3. Васецька Л. І. Організаційно-методичні аспекти навчання мови іноземних студентів-медиків англомовної форми освіти [Електронний ресурс] / Л. І. Васецька, Л. М. Сенік. - Режим доступу : http://www-center.univer. kharkov.ua/vestnik/full/138.pdf. 
4. Масловская А. А. Анализ опыта преподавания биохимии иностранным студентам с английским языком обучения / А. А. Масловская // Журнал ГрГМУ. - 2007. № 1. - С. 226-228.

5. Дзеньдзюра Н. I. Психологія і педагогіка. Проведення індивідуального заняття за методом рольової гри : навч.-метод. посіб. / Н. І. Дзеньдзюра. - Львів : ЛІБС УБС НБУ, 2013. - 38 с.

6. Филипенко С. Л. Рольові ігри як засіб навчання діалогічному мовленню в економічному вузі [Електронний ресурс] / С. Л. Филипенко, С. А. Анісімова. - Режим доступу : http://www.rusnauka.com/2_KAND_2008/ Philologia/25544.doc.htm. 